\title{
Composition and structure of bird communities in vegetational gradients of Bodoquena Mountains, western Brazil
}

\author{
MAURICIO N. GODOI ${ }^{1}$, FRANCO L. SOUZA ${ }^{2}$, RUDI R. LAPS ${ }^{3}$ and DANILO B. RIBEIRO ${ }^{3}$ \\ ${ }^{1}$ Programa de Pós-Graduação em Ecologia e Conservação, Centro de Ciências Biológicas e da Saúde, \\ Universidade Federal de Mato Grosso do Sul, 79070-900 Campo Grande, MS, Brasil \\ ${ }^{2}$ Departamento de Zoologia, Centro de Ciências Biológicas e da Saúde, Universidade Federal de Mato \\ Grosso do Sul, Cidade Universitária, s/n, C.P. 549, 79070-900 Campo Grande, MS, Brasil \\ ${ }^{3}$ Departamento de Ecologia, Centro de Ciências Biológicas e da Saúde, Universidade Federal de Mato \\ Grosso do Sul, Cidade Universitária, s/n, C.P. 549, 79070-900 Campo Grande, MS, Brasil
}

Manuscript received on December 26, 2014; accepted for publication on April 27, 2015

\begin{abstract}
The informations of bird species distribution in different habitats and the structure of their communities are crucial for bird conservation. We tested the differences in composition, richness and abundance of birds in different phytophysiognomies at Bodoquena Mountains, western Brazil, and we demonstrated the variations in richness and abundance of birds between different trophic groups. Sampling was conducted between July 2011 and June 2012 in 200 point counts arranged in the study area. A total of 3350 contacts were obtained belonging to 156 bird species. Woodland savannas, seasonal forests and arboreal savannas had higher bird abundance and richness, while riparian forests, clean pastures and dirty pastures had smaller values of these parameters. The bird community was organized according to local vegetational gradient, with communities of forests, open areas and savannas, although many species occurred in more than one vegetation type. The insectivorous, omnivorous, frugivorous and gramnivorous birds composed most of the community. These data showed how important environmental heterogeneity is to bird communities. Furthermore, the presence of extensive patches of natural habitats, the small distance between these patches and the permeability of pastures, with high arboreal and shrubby cover, are indicated as important factors to maintain the bird diversity.
\end{abstract}

Key words: Cerrado, habitat use, point counts, Private Reserves, trophic groups.

\section{INTRODUCTION}

The Cerrado is the second largest Brazilian phytogeographic domain, occupying almost $25 \%$ of the country, especially in central Brazil (Eiten 1993). Its landscape is caracterized by a mosaic of vegetation types with forests (riparian and seasonal

Correspondence to: Mauricio Neves Godoi

E-mail: mauricioecologia@hotmail.com forests), woodland savannas (cerradão), arboreal savannas (cerrado stricto sensu), natural grasslands (campo cerrado, campo sujo and campo limpo) and wetlands, which include swamps and formations of Buriti palms (Mauritia flexuosa, Arecaceae) locally called veredas (Eiten 1993, Ribeiro and Walter 1998). The great habitat diversity provides high bird richness in the Cerrado domain, comprising 
$45 \%$ of Brazilian avifauna or 856 of the 1900 species registered in Brazil (Silva and Santos 2005, CBRO 2014).

The Cerrado domain is one of the most endangered biodiversity hotspots (Myers et al. 2000 ) and about $60 \%$ of its original vegetation has been converted into pastures, plantations and urban areas, creating a landscape formed by great extensions of anthropogenic matrices with isolated fragments of native vegetation (Machado et al. 2004). However, some mountain regions still maintain large extensions of native vegetation due to the relief and the poor quality of the soil reducing their agriculture capability. In central Brazil these areas are extremely important for avifauna conservation, and in the state of Mato Grosso do Sul there are two of these regions, the Maracaju Mountains (Nunes et al. 2013) and Bodoquena Mountains (Pivatto et al. 2006).

The Bodoquena Mountains are located in the southwestern of Cerrado, and presents biogeographic influences of the Pantanal, the Chaco and of the Atlantic Forest. The biogeographic influences of different domains, the great extensions of natural areas and the habitat diversity of the landscape provide the region with a high animal and plant diversity, making them a priority area for the conservation of the biodiversity of the Cerrado (MMA 1999). In relation to the bird diversity, in Bodoquena Mountains 353 species were recorded, showing that this region has high bird richness in comparation to other areas studied in the Cerrado (Pivatto et al. 2006).

At Bodoquena Mountains the efforts towards to the conservation of biodiversity have been conducted especially by the establishment of protected areas. The Serra da Bodoquena National Park is the most important protected area of the region, maintaining $77.021,58$ ha of natural areas which include the main vegetational types regionally presents. However, other types of protected areas are important too, as Natural Monuments, Environmental Protected Areas (or
APA - Área de Proteção Ambiental) and Private Reserves (or RPPN's - Reservas Particulares do Patrimônio Natural). The Private Reserves, for example, protect almost 1770 ha of natural areas in the Bodoquena Mountains, showing their importance for the regional system of protected areas and to the biodiversity conservation (ICMBIO 2013). These areas are generally small, but are very important to complement the efforts of public conservation. They are fundamental for conservation on a regional scale because they protect populations of different animal and plant species in their natural habitats and function as ecological corridors that contribute to the biological connectivity in fragmented landscapes (Oliveira et al. 2010).

The information about composition and structure of bird communities, as well as on distribution of species in different vegetational types present in a region, are very important for the scientific knowledge and conservation of birds, especially when we consider how quickly the natural environments have been reduced, disturbed and fragmented (Dias 1990).

The objective of this study was to test the differences in composition, species richness and abundance of birds between different phytophysiognomies, showing the importance of the vegetation gradient for the conservation of birds in a protected area located in Bodoquena Mountains, state of Mato Grosso do Sul, Brazil, and additionally present the variations in species richness and abundance of birds between different trophic groups.

\section{MATERIALS AND METHODS}

STUDY AREA

The Bodoquena Mountains, located in southwestern of Mato Grosso do Sul state, western Brazil, comprise 2 million ha, ranging $300 \mathrm{~km}$ long in a north-south direction and 20-50 $\mathrm{km}$ wide from east to west (Boggiani et al. 1993) (Figure 1). The medium 
altitude in the region varies from 400 to $600 \mathrm{~m}$ above sea level, with maximum values of altitude around $770 \mathrm{~m}$ in their northern portion and minimum values just below $300 \mathrm{~m}$ (ICMBIO 2013). Bodoquena Mountains have many headwaters, functioning as extensive watersheds between the Paraguay River basin, located on the west, and the sub-basins of Apa river, located on the south, and the Miranda river, located on the east (ICMBIO 2013).

The climate of the region is Aw, or tropical sub-warm, according to Köppen classification, with medium annual temperatures between $22{ }^{\circ} \mathrm{C}$ and $26{ }^{\circ} \mathrm{C}$, maximum temperatures around $35^{\circ} \mathrm{C}$ and $40{ }^{\circ} \mathrm{C}$, and minimal which could reach near 0 ${ }^{\circ} \mathrm{C}$. The relative air umidity is low, rarely reaching $80 \%$, and the medium annual precipitation is 1400 $\mathrm{mm}$, with a hot and rainy season from November to March, and a dry season from April to October (IBGE 2006).

The Bodoquena Mountains are located in transitional areas under influence of Cerrado and Pantanal domains (Veloso et al. 1991), but they are also influenced by Atlantic Forest and Chaco. The regional landscape is a complex mosaic of vegetation types, dominated by decidual and semidecidual seasonal forests, especially in mountainous areas, riparian forests, woodland savannas (cerradão), arboreal savannas (cerrado stricto sensu), grasslands, swamps, artificial pastures and disturbed areas in different stages of natural regeneration (Brasil 1997, Pott and Pott 2003).

In Bodoquena Mountains the area chosen for this study was a private protected area called RPPN Estância Mimosa and some areas around it (2058'57.70”'S; 56³0'58.40”O; $390 \mathrm{~m}$ above sea level). The study area (referred hereinafter as EM) is located $18 \mathrm{~km}$ north of Bonito municipality, state of Mato Grosso do Sul, Brazil (Figure 1). The EM has a total of 800 ha, of which 278.42 ha belonging to RPPN Estância Mimosa.

In the study area there is a vegetation gradient formed by riparian forests associated to the Mimoso river, extensive patches of seasonal forests and arboreal savannas (cerrado stricto sensu), in addition to patches of woodland savannas (cerradão) and pastures with different levels of arboreal and shrubby cover (clean and dirty pastures). The cattle ranching in this area is developed into silvopasture system, maintaining trees in pastures, which are usually small and are surrounded by large patches of natural habitats.

The riparian forests are always associated to watercourses. These forests are generally evergreen, have continuous canopy (coverage of 70 to $90 \%$ ) and have trees ranging from 20 to 25 $\mathrm{m}$ in height, possible reaching $30 \mathrm{~m}$. Seasonal forests occur in interfluvial areas, generally on rich soils. Their trees range from 15 to $25 \mathrm{~m}$ in height and form a continuous canopy with 70 to $95 \%$ of arboreal cover, although there is a drastic reduction in this cover during the dry season due to the deciduousness of many plant species. The woodland savannas (cerradão) are forest formations of the Cerrado domain which have relatively continuous canopy (50 to $90 \%$ of cover) and tree layer with 8 to $15 \mathrm{~m}$ in height. The lower height of the trees and the deciduousness of many plant species in the woodland savannas allow better luminosity and consequently major density of understory, with great density of small schrubs. The arboreal savannas (cerrado stricto sensu) are savanic formations with tree, shrub and herb layers well defined. Their trees are small (3 to $8 \mathrm{~m}$ in height), twisted, formed a discontinuous canopy (20 to $70 \%$ of cover) and generally present burn evidences. The schrub and herb layers are dense, especially in rainy seasons (Eiten 1993, Ribeiro and Walter 1998).

\section{FIELD METHODS}

The study area was delimited in a rectangle with 800 ha divided into 280 grids of $200 \times 200$ m, of which 200 were randomly selected. In the center 


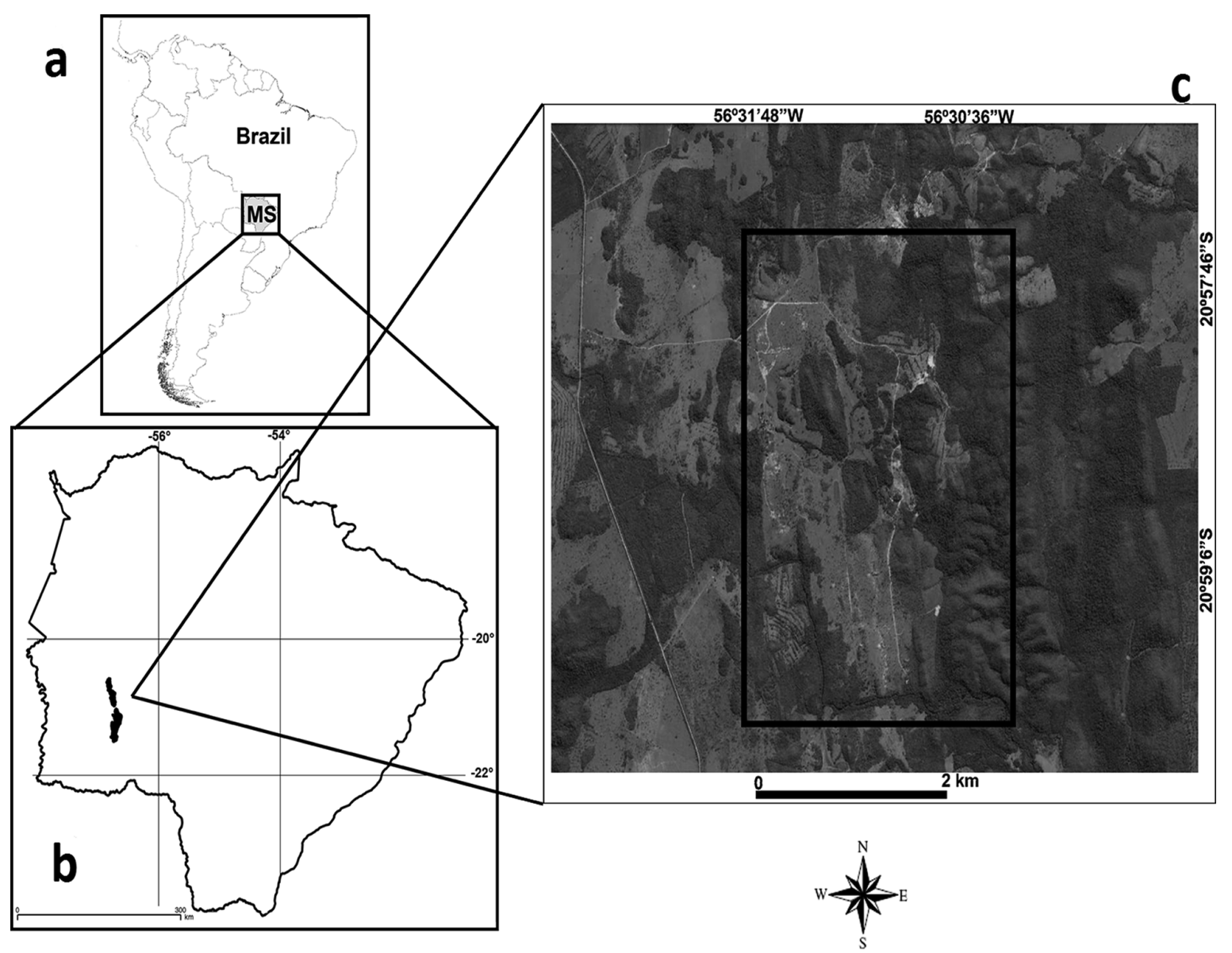

Figure 1 - Localization of Bodoquena Mountains and the study area (black rectangle), Bonito municipallity, state of Mato Grosso do Sul (MS), Brazil.

of each grid a point count was established, with a fixed radius of $50 \mathrm{~m}$ and $200 \mathrm{~m}$ of minimal distance from any other point (Develey 2004, Anjos et al. 2010, Vielliard et al. 2010). Each point count was established in one vegetation type, avoiding ecotones. By this method, areas of riparian forests $(n=9)$, seasonal forests $(n=49)$, woodland savannas $(n=18)$, arboreal savannas $(n=39)$, dirty pastures $(n=45)$ and clean pastures $(n=40)$ were sampled during 12 consecutive months, between July 2011 and June 2012, equally covering the wet and dry seasons.

Each point count, which represents a sample unit, was visited only once during the study for 15 minutes in the earling morning, between 06:00 and 08:30, when most bird species were active. The points were sampled randomly, and on each day we sampled the drawned point and the four nearest points.

\section{DATA ANALYSIS}

For each point count we recorded composition, richness and number of contacts per species. The species abundance was expressed by total number of contacts and Punctual Abundance Index (PAI), which is a ratio between the total number of specie's contacts by total number of samples used in the study (Anjos et al. 2010, Vielliard et al. 2010). The PAI of each species was calculated for all study area and for each vegetation type, separately.

To evaluate if the sampling effort applied was enough to capture a non-biased sample of the entire 
community, a randomized collector curve was made. This curve was made with the cumulative number of species sampled by the number of samples (point counts) used. The species richness was also estimated using the Bootstrap estimator (Colwell and Coddington 1994).

The differences in avifauna abundance and richness between the vegetation types were tested by Analysis of Variance (ANOVA). The community ordination in relation to composition and abundance of species was performed by NonMetric Multidimensional Scaling (NMDS) with two dimensions using distance indices of BrayCurtis. Additionally, an Analysis of Similarity (ANOSIM) with the sequential Bonferroni test was calculated to verify the level of similarity between the bird communities of different vegetation types.

The representation of each trophic group in the community was determined by species richness and bird abundance (number of contacts) in each group. The species classification in trophic groups was based on classifications commonly used in scientific literature (Karr et al. 1990, Motta-Junior 1990, Sick 1997) and on records of bird feedings obtained in field expeditions. The bird species were classified according to principal food itens consumed: insectivores (arthropods), frugivores (fruits), omnivores (arthropods, fruits and small vertebrates), gramnivores (seeds), nectarivores (nectar), carnivores (terrestrial vertebrates captured alive), piscivores (fishes), malacofagous (molluscs) and necrofagous (dead vertebrates).

The taxonomic classification and nomenclature adopted in this study followed the Brazilian Comitee of Ornithological Records (CBRO 2014). All analyses used in this study were made on software R (R Core Team 2013) and "VEGAN" package (Oksanen et al. 2009).

\section{RESULTS}

In this study were obtained 3350 records of 156 bird species, belonging to 41 families and 19 orders (Table SI - Supplementary Material). The randomized collector's curve, which considers the cumulative number of bird species as a function of samples used, showed trends of stabilization. The observed richness corresponded to $92.8 \%$ of the estimated richness (168.8 species \pm 3.2 ). These results showed that the number of samples used was sufficient for sampling most bird species of the study area (Figure 2).

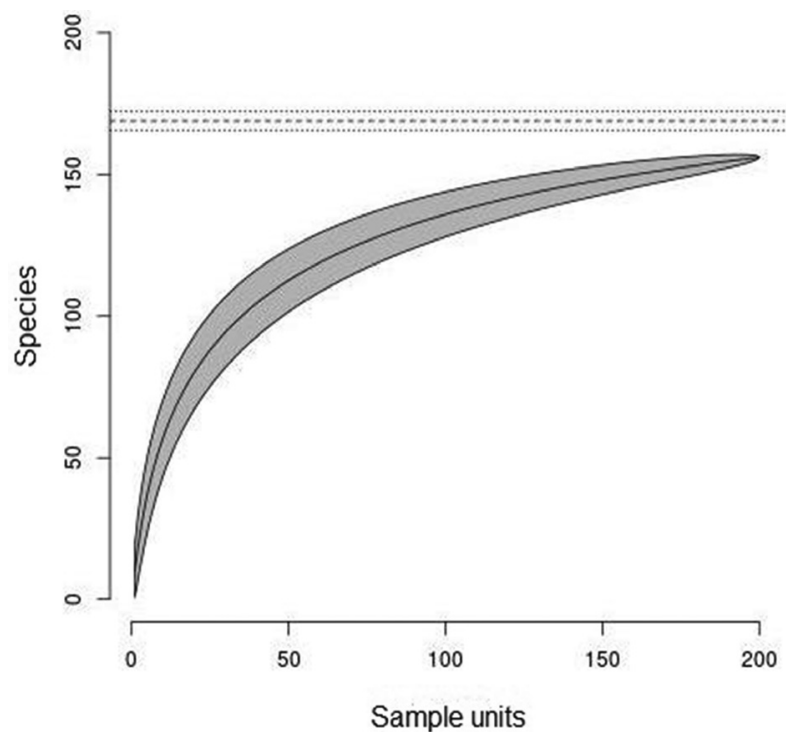

Figure 2 - Randomized collector curve with average and standard deviation of observed (continuous line) and estimated richness (dashed line) of the bird communities at Estância Mimosa, Bodoquena Mountains, state of Mato Grosso do Sul, Brazil.

The greatest values of species richness were obtained in the woodland savannas $(13.1 \pm 4.9$; $\mathrm{n}=18)$, seasonal forests $(12.6 \pm 3.9 ; \mathrm{n}=49)$ and arboreal savannas $(10.9 \pm 3.9 ; \mathrm{n}=39)$, with the smallest richness in clean pastures $(7.8 \pm 3.3 ; \mathrm{n}=$ $40)$, dirty pastures $(7.6 \pm 4.3 ; \mathrm{n}=45)$ and riparian forests $(6.8 \pm 5.08 ; n=9)$ (Figure 3$)$. The vegetation types which showed the highest bird abundance were also the woodland savannas $(20.8 \pm 7.1$; $n$ $=18)$, seasonal forests $(19.8 \pm 6.9 ; \mathrm{n}=49)$ and arboreal savannas $(17.3 \pm 6.4 ; \mathrm{n}=39)$, and those with smaller abundances were clean pastures (15.2 $\pm 8.3 ; \mathrm{n}=40)$, dirty pastures $(13.3 \pm 7.7 ; \mathrm{n}=45)$ 
and riparian forests $(12.5 \pm 6.8 ; \mathrm{n}=9)$ (Figure 4). The vegetational types were significantly different in relation to species richness $\left(\mathrm{F}_{5,194}=12.93, \mathrm{p}\right.$ $\leq 0.0001)$ and bird abundance $\left(\mathrm{F}_{5,194}=5.74, \mathrm{p}<\right.$ $0.001)$.

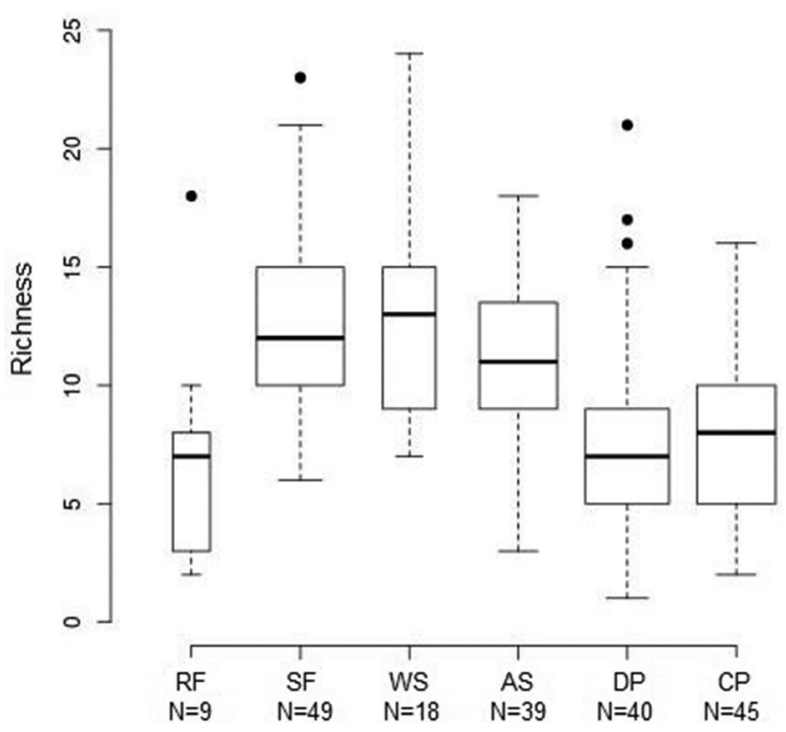

Figure 3 - Bird species richness in riparian forests (RF), seasonal forests (SF), woodland savannas (WS), arboreal savannas (AS), dirty pastures (DP) and clean pastures (CP), at Estância Mimosa, Bodoquena Mountains, state of Mato Grosso do Sul, Brazil. N = number of samples.

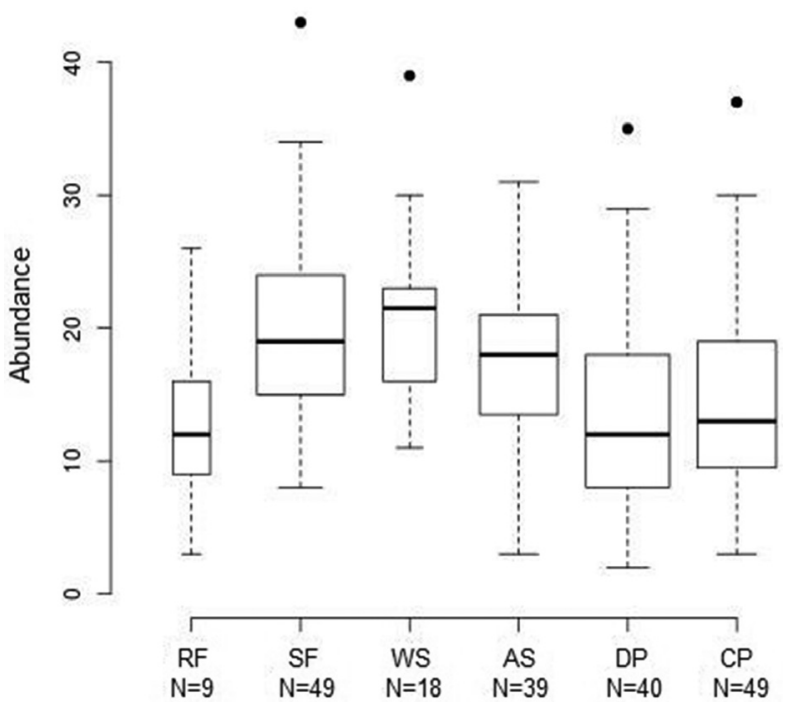

Figure 4 - Bird abundance in riparian forests (RF), seasonal forests (SF), woodland savannas (WS), arboreal savannas (AS), dirty pastures (DP) and clean pastures (CP), at Estância Mimosa, Bodoquena Mountains, state of Mato Grosso do Sul, Brazil. $\mathrm{N}=$ number of samples.
The ordination analysis showed there is a trend to separation the bird community at EM between forest formations (seasonal and riparian forests) and open areas (clean pastures), with communities of dirty pastures, arboreal and woodland savannas being intermediate in this vegetational gradient (NMDS, stress: 0.23; $\mathrm{R}^{2}=0.759$ ) (Figure 5). The similarity analysis indicated differences in bird community composition between the vegetation types (Anosim, $\mathrm{R}=0.327, \mathrm{p} \leq 0.0001$ ), but just woodland savannas and dirty pastures $(\mathrm{R}=0.002$, $\mathrm{p}=0.45)$ and woodland savannas and arboreal savannas $(\mathrm{R}=0.01, \mathrm{p}=0.33)$ presented similar bird communities.

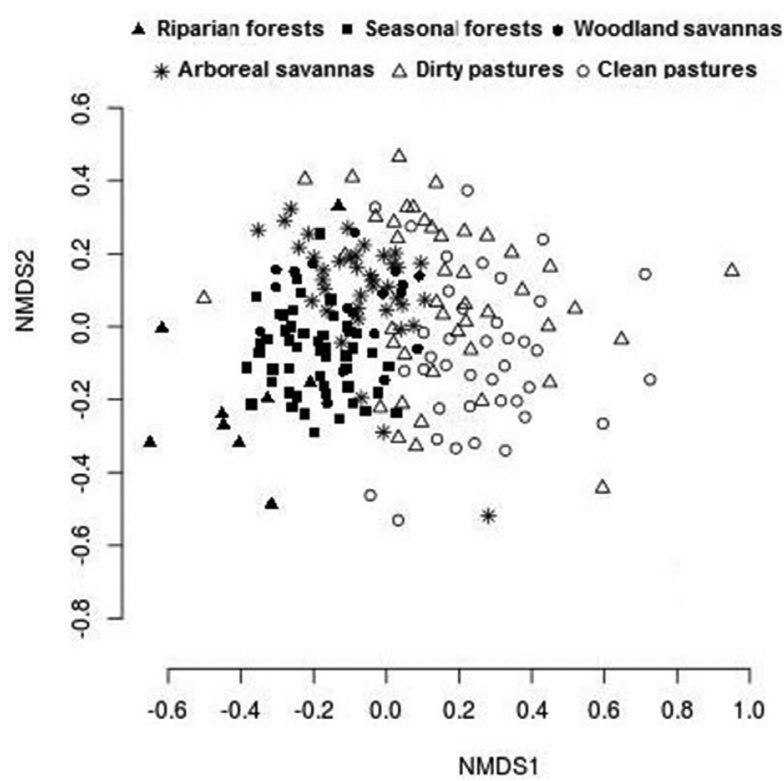

Figure 5 - Non-Metric Multidimensional Scaling (NMDS, Bray-Curtis distance) (Stress $=0.23 ; \mathrm{R}^{2}=0.759$ ) of bird community in different vegetation types at Estância Mimosa, Bodoquena Mountains, state of Mato Grosso do Sul, Brazil.

The insectivores, omnivores, frugivores and gramnivores were the most abundant and rich guilds in the bird community (Table SI; Figure 6). We obtained 1213 contacts of 67 insectivorous species, 1390 contacts of 46 omnivorous species, 349 contacts of 13 frugivorous species and 257 contacts of 12 gramnivorous species. The other trophic groups presented smaller abundance and species richness (Table SI; Figure 6). 

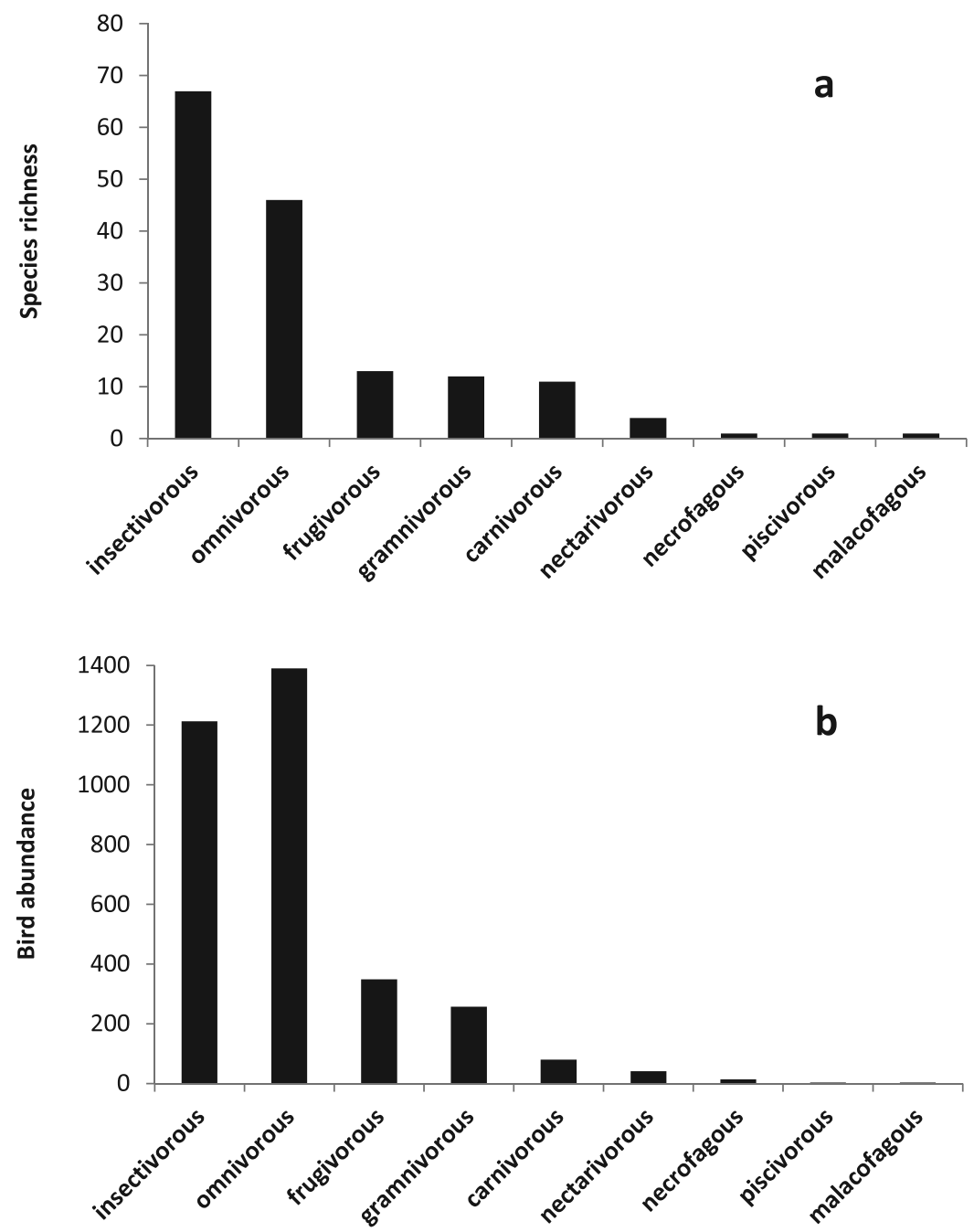

Figure 6 - Species richness (a) and bird abundance (b) of different trophic groups at Estância Mimosa, Bodoquena Mountains, state of Mato Grosso do Sul, Brazil.

\section{DISCUSSION}

We recorded 247 bird species at EM by joint application of qualitative and quantitative sample methods (Godoi et al. 2014). The bird species richness observed in this study by point counts (156 species) represented $63.2 \%$ of the known bird richness for all study area, showing the efficiency of this method to record the most bird species of a region (Develey 2004, Anjos et al. 2010, Vielliard et al. 2010). Additionally, the method of point counts is very suitable when the objective is to provide controlled data on the bird abundance, being widely used in studies on bird community structure (Aleixo and Vielliard 1995, Aleixo 1999, Almeida et al. 1999, Pozza and Pires 2003, Donatelli et al. 2004, 2007, Lyra-Neves et al. 2004, Telles and Dias 2010).

The bird abundance and richness varied in the different vegetational types at EM. The mean values of richness and abundance were larger in seasonal forests, woodland savannas and arboreal savannas, and lower in pastures. This result agrees with studies conducted in other Cerrado localities, where bird communities were normally more diversified in seasonal forests, patches of woodland 
savannas and arboreal savannas, when compared with natural and anthropogenic open areas (Fry 1970, Tubelis and Cavalcanti 2000, 2001, Santos 2001, Piratelli and Blake 2006, Faria et al. 2009).

In this context, it was expected that riparian forests at EM would also present high bird abundance and species richness, because they have structurally heterogeneous environments and are usually mentioned as very rich formations in bird species in the Cerrado domain (Silva 1996, Silva and Bates 2002, Faria et al. 2009, Valadão 2012). However, the riparian forests at EM presented low bird abundance and species richness, which may be attributed to the small area occupied by this physiognomie in the study area and the small number of samples utilized in them.

Vegetational formations which have greater heterogeneous structures, such as greater vertical stratification, for example, usually have higher richness and abundance of birds, a pattern that has been explained by the hypothesis of environmental heterogeneity. This hypothesis assumes that structurally more heterogeneus habitats may provide more ecological niches, allowing major diversification in resource exploitation, which would cause an increase in the species diversity (MacArthur and MacArthur 1961, Tews et al. 2004). The heterogeneity may be provided, for example, by vegetation structure, which in turn is determined by vegetational communities (MacArthur and MacArthur 1961, MacArthur et al. 1962). Thus, even in small spatial scales, the vegetation structure seems to determine the distribution and abundance of species, promoting changes in the composition and structure of bird communities between different habitat types (Blake and Loiselle 2000, Tews et al. 2004).

Despite the differences in bird abundance and richness between the vegetational types, one should highlight the importance of habitat diversity at EM with regard to the local bird conservation. The birds of the Cerrado domain need a mosaic of vegetation types to maintain their populations, since most of them perform daily and seasonal movements between these areas to forage. Thus, it is important to maintain the habitat diversity in the Cerrado domain to provide resource availability for the birds throughout the year (Tubelis et al. 2004).

In relation to composition and structure, the different vegetation types atEM presented particular bird communities, especially seasonal and riparian forests, which had species exclusively sampled in these areas. Seasonal forests, for example, had bird species which are most commonly found in the Atlantic Forest domain, like Ramphastos dicolorus and Melanerpes flavifrons (Goerck 1997, Brooks et al. 1999). These results showed seasonal forests allow that different Atlantic species may expand their distributions to the west, for regions of Cerrado domain (Straube et al. 1996, Pivatto et al. 2006). The seasonal forests at EM also seem to be the main habitat for some species that need relatively large forests to maintain their populations, like large forest birds such as Penelope superciliaris, Micrastur ruficollis and Pulsatrix perspicillata, and small insectivorous birds which depend on forest understory, like Herpsilochmus atricapillus, Thamnophilus caerulescens, Corythopis delalandi and Cantorchilus guarayanus.

The riparian forests at EM also presented bird species which only occur or were more abundant in these areas, like Aramus guarauna, Crotophaga major, Chloroceryle amazona, Momotus momota, Myiozetetes cayanensis and Myiarchus ferox. These forests usually have high species richness and particular bird communities, with species strongly associated with these formations (Fry 1970, Silva and Vielliard 2004, Piratelli and Blake 2006, Faria et al. 2009, Posso et al. 2013). These forests also function as refuges to birds of adjacent savannas (Silva and Bates 2002, Tubelis et al. 2004) and as corridors that allow the expansion of Amazon and Atlantic forest species to the interior of the Cerrado (Silva 1996). 
The clean pastures at EM also presented distinct bird communities in relation to other vegetation types. In these pastures many birds typical of open areas occurred, like Theristicus caudatus, Caracara plancus, Cariama cristata, Vanellus chilensis, Eupsittula aurea, Athene cunicularia, Colaptes campestris, Furnarius rufus, Sicalis flaveola and Gnorimopsar chopi. These species usually occur in natural and anthropic open areas of the Cerrado and other phytogeographic domains, even in disturbed areas by deforestation in forest regions (Silva 1995, Sick 1997).

The arboreal savannas (cerrado stricto sensu) and woodland savannas (cerradão) of the EM presented great similarity in bird community composition, such as in areas of the Cerrado located in the east of the state of Mato Grosso do Sul (Piratelli and Blake 2006). These formations, together with the dirty pastures, formed an intermediary group between the bird communities of forests and clean pastures. The arboreal and woodland savannas presented 61 species in common, which represents $82.4 \%$ and $80.2 \%$ of their communities, respectively.

The arboreal savannas usually present many particular species, but can also be inhabited by grassland and forest bird species (Tubelis et al. 2004, Piratelli and Blake 2006, Posso et al. 2013). The most abundant birds in arboreal savannas at EM were species typically found in these areas, such as Euphonia chlorotica, Myiarchus tyrannulus, Hemithraupis guira, Lepidocolaptes angustirostris, Ramphastos toco, Hemitriccus margaritaceiventer, Hylocharis chrysura and Nystalus striatipectus. But in these areas also occur forest species which have great movement capacity at landscape, such as Pyrrhura devillei, Cyanocorax cyanomelas, Turdus leucomelas and Pteroglossus castanotis. A few grassland species occurred in the arboreal savannas at EM, like Cariama cristata and Sicalis flaveola, recorded especially in more open arboreal savannas or on the edge of these environments.
Thewoodland savannas is a forest physiognomy of the Cerrado domain which is habitat for many bird species that also occur in seasonal and riparian forests (Piratelli and Blake 2006, Valadão 2012, Posso et al. 2013). However, at EM the birds of these savannas were more similar to birds of arboreal savannas. Thus, the bird communities of woodland savannas were formed especially by species capable of inhabiting both forest and savanna formations. Some species which were usually most common in forests occurred in woodland savannas at EM (Cyanocorax cyanomelas, Turdus leucomelas, Sirystes sibilator, Myiothlypis flaveola, Casiornis rufus), such as some species which were most common in arboreal savannas (Euphonia chlorotica, Pitangus sulphuratus, Lepidocolaptes angustirostris, Ramphastos toco, Myiarchus tyrannulus).

The dirty pastures at EM presented bird communities more similar to those of woodland savannas. These formations presented 54 species in common, which comprises $58 \%$ of the birds of dirty pastures and $72.9 \%$ of the community of woodland savannas. Thus, dirty pastures indicated being capable of harboring many bird species present in surrounding forests and savannas. This was possible because dirty pastures have many trees and schrubs, which can be used as stepping stones, making pastures more permeable for foraging and movement of bird species between patches of native vegetation (Silva et al. 1996, Estrada et al. 2000). In addition, some plant species which colonize pastures offer a large abundance of fruits, making them more permeable to the birds. This is the case of capororoca (Rapanea guianensis, Myrsinaceae), a common tree found in savannas and dirty pastures of the study area and belonging to a genus of plants known to be important in the diet of some birds (Pineschi 1990, Francisco and Galetti 2001, Pascotto 2007).

Insectivorous, omnivorous, frugivorous and gramnivorous birds were dominant at EM and in 
each particular vegetation type. These groups are usually dominant in the Cerrado domain (MottaJunior 1990, Donatelli et al. 2004, Piratelli and Blake 2006, Manica et al. 2010, Telles and Dias 2010, Vieira et al. 2013) and other Brazilian phytogeographic domains (Willis 1979, Aleixo 1999, Anjos 2001, Silveira et al. 2003, Santos 2004, Olmos et al. 2005, Telino-Júnior et al. 2005, Roos et al. 2006, Donatelli et al. 2007, Silveira and Machado 2012).

The dominance of insectivorous birds could be related to the great abundance of arthropods and the relatively regular supply of these resources. Thus, maintaining a diet of arthropods may be a safer strategy for the birds than the consumption of fruits, which usually have more irregular availability in space and time, especially in vegetational mosaics of forests and grasslands with seasonal precipitation regime, like in Bodoquena Mountains (Reys et al. 2005), as well as throughout the Cerrado domain (Batalha and Mantovani 2000, Batalha and Martins 2004). The adoption of an omnivorous diet, with a regular consumption of fruits, arthropods and vertebrates, often makes the species less sensitive to habitat degradation and fragmentation, since a varied diet allows the birds to forage in different vegetation types and grants them regular food supply throughout the year. Because of this, some omnivorous birds become abundant in disturbed habitats at the same time more specialized birds, both insectivorous and frugivorous, become rare in these areas (Willis 1979).

The gramnivorous birds were most common at EM in pastures and arboreal savannas because the seeds of grasses, which are the main food item for some common bird species, like Volatinia jacarina and Sicalis flaveola, are more abundant in grasslands and savannas of the Cerrado domain (Motta-Junior 1990). Although nectarivorous birds have been poorly observed, they seem to be more common in arboreal savannas, corroborating data from other areas of the Cerrado in central Brazil
(Piratelli and Blake 2006, Vieira et al. 2013). Malacofagous and piscivorous birds only occurred in riparian forests, since these are the only areas with rivers and streams where their food resources could be found. Finally, carnivorous birds were represented by few species, just like in other studies (Motta-Junior 1990, Donatelli et al. 2004, Manica et al. 2010), since top predators occupy large territories and are naturally rare.

In relation to conservation, two main groups of species should be highlighted: insectivorous birds that live in forest understory and forest frugivorous birds, especially large species. The understory insectivorous birds are very sensitive to the loss and fragmentation of forests (Willis 1979, Bierregaard Jr and Lovejoy 1989), since many species cannot maintain viable populations in small and isolated forest fragments or cross open areas to move between fragments (Stouffer and Bierregaard Jr 1995, Canaday 1997, Marini 2001, Sekercioglu et al. 2002, Martensen et al. 2008). Large forest frugivorous birds (Crax fasciolata, Aburria cumanensis, Penelope superciliaris, Ramphastos dicolorus, Pteroglossus castanotis) are very sensitive too (Willis 1979, Price et al. 1999), because they need large patches of native vegetation or well connected remaining areas to forage on fruiting trees. The conservation of frugivorous birds is extremelly important for the natural ecossystems because they act as seed dispersers, promoting the reproduction of many plant species and the regeneration of natural environments (Levey 1988, Silva et al. 1996, Pizo 2001).

The high species richness observed at EM, with many birds dependent or semidependent on forests (Godoi et al. 2014), the presence of endangered species and species sensitive to loss and fragmentation of forests, as the large frugivorous and understory insectivorous birds, can be atributted to some main factors. Firstly, the maintenance of fragments near areas which still retain large extensions of natural environments, 
mainly seasonal forests and arboreal savannas. The proximity of large areas of native vegetation certainly contributed to increase the bird species diversity in disturbed areas in addition to increasing the presence of sensitive species in fragmented landscapes (Aleixo 1999, Marsden et al. 2001, Faria et al. 2006).

Another important issue related to the bird conservation is the permeability of the anthropogenic matrix to the birds dependent and semidependent of forests, especially in the dirty pastures. Production systems which allow the maintenance of structurally complex habitats increase the permeability of the landscape to local biodiversity, when compared to other systems that simplify the environment by cutting trees, for example (Pimentel et al. 1992, Estrada et al. 1993a, b, 1994, Perfecto et al. 1996, Greenberg et al. 1997, Rice and Greenberg 2000, Sherry 2000, Faria et al. 2006). Thus, maintaining part of the shrub and arboreal strata in pastures certainly contributes to the local bird conservation, since it increases the area of available habitat and facilitates the movement of bird species in the landscape.

\section{ACKNOWLEDGMENTS}

The authors are very grateful to Eduardo and Simone Coelho, the owners of RPPN Estância Mimosa, for the opportunity and logistical support to carry out this study on their farm, and to RPPN staff for their help and hospitality during field collections. The authors also thank the reviewers of this article for their important contributions. Mauricio Neves Godoi thanks the Universidade Federal de Mato Grosso do Sul and Coordenação de Aperfeiçoamento de Pessoal de Nível Superior (CAPES) for financial support through a doctoral scholarship. Franco Leandro de Souza is funded by a research grant from Conselho Nacional de Desenvolvimento Científico e Tecnológico (CNPq, 301071/2011-0).

\section{RESUMO}

As informações de distribuição das espécies de aves em diferentes habitats e a estrutura de suas comunidades são cruciais para sua conservação. Nós testamos as diferenças na composição, riqueza e abundância de aves em diferentes fitofisionomias da Serra da Bodoquena, oeste do Brasil, e demonstramos as variações na riqueza e abundância de aves entre diferentes grupos tróficos. As amostragens foram conduzidas entre Julho de 2011 e Junho de 2012 em 200 pontos de escuta distribuídos na área de estudo. Foram obtidos 3350 contatos pertencentes a 156 espécies de aves. Savanas florestadas, florestas estacionais e savanas arborizadas tiveram maior riqueza e abundância de aves, enquanto florestas ripárias, pastos limpos e pastos sujos tiveram menores valores destes parâmetros. A comunidade de aves foi organizada de acordo com o gradiente local de vegetação, com comunidades de florestas, áreas abertas e savanas, embora muitas espécies tenham ocorrido em mais de um tipo de vegetação. As aves insetívoras, onívoras, frugívoras e granívoras compreenderam a maioria da comunidade. Estes dados demonstraram quão importante é a heterogeneidade ambiental para as comunidades de aves. Além disso, a presença de extensas manchas de habitats naturais, a pequena distância entre estas manchas e a permeabilidade das pastagens, com alta cobertura arbórea e arbustiva, são apontadas como importantes fatores para a manutenção da diversidade de aves.

Palavras-chave: Cerrado, uso do habitat, pontos de escuta, Reserva Particular, grupos tróficos.

\section{REFERENCES}

ALEIXO A. 1999. Effects of selective logging on a bird community in the Brazilian Atlantic Forest. The Condor 101: 537-548.

AleiXo A AND Vielliard JME. 1995. Composição e dinâmica da avifauna da Mata de Santa Genebra, Campinas, São Paulo, Brasil. Rev Bras Zool 12(3): 493-511.

ALMEIDA MEC, VIELLIARD JME AND DiAS MM. 1999. Composição da avifauna em duas matas ciliares na bacia do rio Jacaré-Pepira, São Paulo, Brasil. Rev Bras Zool 16(4): 1087-1098.

ANJos L. 2001. Bird communities in natural forest patches in southern Brazil. Wilson Bull 111: 397-414.

Anjos L, Volpato GH, Mendonça LB, SERAFini PP, LOPES EV, BOÇON R, SILVA ES AND BISHEIMER MV. 
2010. Técnicas de levantamento quantitativo de aves em ambiente florestal: uma análise comparativa baseada em dados empíricos. In: Von Matter S et al. (Eds), Ornitologia e Conservação. Ciência Aplicada, Técnicas de Pesquisa e Levantamento. Technical Books Editora, Rio de Janeiro, RJ, p. 61-76.

BATAlHa MA AND MANTOVAni W. 2000. Reproductive phenological patterns of cerrado plant species at the Pe-deGigante Reserve (Santa Rita do Passa Quatro, SP, Brazil): a comparison between the herbaceous and woody floras. Rev Bras Biol 60(1): 129-145.

BATAlHA MA AND MARTINS FR. 2004. Reproductive phenology of the cerrado plant community in Emas National Park. Aust J Bot 52(2): 149-161.

BIERREGAARD JR RO AND LOVEJOY TE. 1989. Effects of forest fragmentation on Amazonian understory bird communities. Acta Amaz 19: 215-241.

BLAKE JG AND LOISELLE BA. 2000. Diversity of birds along an elevational gradient in the Cordillera Central, Costa Rica. Auk 117(3): 663-686.

BOGGIANI PC, FAIRCHILD TR AND COIMBRA AM. 1993. O grupo Corumbá (Neoproterozóico-Cambriano) na região central da Serra da Bodoquena (Faixa Paraguai), Mato Grosso do Sul. RBG 23(3): 301-305.

BRASIL. 1997. Plano de Conservação da Bacia do Alto Paraguai - PCBAP / Projeto Pantanal. Programa Nacional de Meio Ambiente PNMA, Brasília, DF 3: 50-60.

BROOKS T, TOBIAS J AND BALFORD A. 1999. Deforestation and bird extinction in the Atlantic Forest. Anim Conserv 2: 211-222.

CANADAY C. 1997. Loss of insectivorous birds along a gradient of human impact in Amazonia. Biol Conserv 77: 63-77.

CBRO - COMITÊ BRASILEIRO DE REgISTROS ORNITOLÓGICOS. 2014. Lista das aves do Brasil. http://www.cbro. org.br. Accessed on April 15, 2014.

COLWELL RK AND CODDINGTON JA. 1994. Estimating terrestrial biodiversity through extrapolation. Philos Trans R Soc Lond B 345: 101-118.

DEVELEY PF. 2004. Métodos para estudos com aves. In: Cullen L et al. (Eds), Métodos de Estudos em Biologia da Conservação e Manejo da Vida Silvestre, Editora Universidade Federal do Paraná (UFPR), Curitiba, Paraná, p. $153-168$.

DIAS BFS. 1990. Conservação da natureza no cerrado brasileiro. In: Pinto MN (Ed), Cerrado: caracterização, ocupação e perspectivas, Editora Universidade de Brasília (UNB), Brasília, DF, p. 583-640.

DONATElli RJ, COSTA TVV AND FERREIRA CD. 2004. Dinâmica da avifauna em fragmento de mata na Fazenda Rio Claro, Lençóis Paulista, São Paulo, Brasil. Rev Bras Zool 21: 97-114.

DONATELli RJ, FERreira CD, DALBETO AC AND POSSO SR. 2007. Análise comparativa da assembléia de aves em dois remanescentes florestais no interior de São Paulo, Brasil. Rev Bras Zool 24(2): 362-375.
EITEN G. 1993. Vegetação do Cerrado. In: Pinto MN (Ed), Cerrado: caracterização, ocupação e perspectivas, Editora Universidade de Brasília (UNB), Brasília, DF, p. 17-73.

ESTRADA A, CAMMARANO P AND COATES-ESTRADA R. 2000. Bird species richness in vegetation fences and in strips of residual rain forest vegetation at Los Tuxtlas, Mexico. Biodivers Conserv 9: 1399-1416.

ESTRADA A, COATES-ESTRADA R AND MERITT JR D. 1993a. Bat species richness and abundance in tropical rain forest fragments and in agricultural habitats at Los Tuxtlas, Mexico. Ecography 16: 309-318.

ESTRADA A, COATES-ESTRADA R AND MERITT JR D. 1994. Non flying mammals and landscape changes in the tropical rain forest region of Las Tuxtlas, Mexico. Ecography 17: 229-241.

Estrada A, CoAtes R, Meritt JR D, MONTIEL S AND CURIEL D. 1993b. Patterns of frugivore species richness and abundance in forest islands and agricultural habitats at Los Tuxtlas, Mexico. Vegetatio 107/108: 245-257.

FARIA D, LAPS RR, BAUMGARTEN J AND CETRA M. 2006. Bat and bird assemblages from forests and shade cacao plantations in two contrasting landscapes in the Atlantic Forest of southern Bahia, Brazil. Biodivers Conserv 15: 587-612.

FARIA LCP, CARRARA LA, AMARAL FQ, VASCONCELOS MF, DINIZ MG, ENCARNAÇÃO CD, HOFFMANN D, GOMES HB, LOPES LE AND Rodrigues M. 2009. Aves da Fazenda Brejão: uma área prioritária para conservação do Cerrado no noroeste de Minas Gerais, Brasil. Biota Neotrop 9(3): 223-240.

FRANCISCO MR AND GALETTI M. 2001. Frugivoria e dispersão de sementes em Rapanea lancifolia (Myrcinaceae) por aves em uma área de Cerrado no estado de São Paulo, sudeste do Brasil. Ararajuba 9(1): 13-19.

FRY CH. 1970. Ecological distribution of birds in northeastern Mato Grosso State, Brazil. An Acad Bras Cienc 42: 275-318.

Godoi MN, PIVATto MAC, MELlo AV, LAPS RR AND SouZA FL. 2014. Aves da RPPN Estância Mimosa, Serra da Bodoquena, Mato Grosso do Sul, Brasil. Atual Ornitol 178: 39-49.

GoERCK JM. 1997. Patterns of rarity in the Birds of the Atlantic Forests of Brazil. Conserv Biol 11: 112-118.

GreEnberG R, BiCHIER P, ANGON AC AND STERLING J. 1997. Bird populations in rustic and planted coffee plantations of Eastern Chiapas, México. Biotropica 29: 501-514.

IBGE - INSTITUTO BRASILEIRO DE GEOGRAFIA E ESTATÍSTICA. 2006. Diretoria de Geociências, Mapa das Unidades de Relevo. http://www.ibge.gov.br. Accessed on March $25,2013$.

ICMBIO - INSTITUTO CHICO MENDES DE CONSERVAÇÃO DA BIODIVERSIDADE. 2013. Plano de Manejo do Parque Nacional da Serra da Bodoquena. Encarte 2. Brasília, DF, 91 p. http://www.icmbio.gov.br/portal/biodiversidade/ unidadesdeconservacao/biomasbrasileiros/cerrado/ 
unidades-de-conservacao-cerrado/2082-parna-da-serrada-bodoquena.html. Accessed on April 16, 2014.

KARR JR, ROBINSON SK, BLAKE JG AND BIERREGAARD RO. 1990. Birds of four neotropical rainforests. In: Gentry AH (Ed), Four Neotropical Rainforests, Yale University Press, New Haven, p. 237-268.

LEVEY DJ. 1988. Spatial and temporal variation in Costa Rican fruit and fruit-eating bird abundance. Ecol Monogr 58: 251-269.

LYRA-NEVES RM, DIAS MM, AZEVEDO-JÚNIOR SM, TELINO-JÚNIOR WR AND LARRAZÁBAL MEL. 2004. Comunidades de aves da Reserva Estadual de Gurjaú, Pernambuco, Brasil. Rev Bras Zool 21(3): 581-592.

MACARTHUR R AND MACARTHUR J. 1961. On bird species diversity. Ecology 43: 594-598.

MACARTHUR RH, MACARTHUR JW AND PREER J. 1962. On bird species diversity: II. Prediction on bird census from habitat measurements. Am Nat 46: 167-174.

Machado RB, Ramos Neto MB, PEREIRA PGP, CALDAS EF, GONÇALVES DA, SANTOS NS, TABOR K AND STEININGER M. 2004. Estimativas de perda da área do Cerrado brasileiro, Conservação Internacional, Brasília, DF, $26 \mathrm{p}$.

MANICA LT, TELLES M AND DiAs MM. 2010. Bird richness and composition in a Cerrado fragment in the State of São Paulo. Braz J Biol 70(2): 243-254.

MARINI MA. 2001. Effects of forest fragmentation on birds of the cerrado region, Brazil. Bird Conserv Int 11: 13-25.

MARSDEN SJ, WHIFFIN M AND GALETTI M. 2001. Bird diversity and abundance in forest fragments and Eucalyptus plantations around an Atlantic Forest reserve, Brazil. Biodivers Conserv 10: 737-751.

MARTEnsen AC, PiMentel RG AND MetzGer JP. 2008. Relative effects of fragment size and connectivity on bird community in the Atlantic Rain Forest: Implications for conservation. Biol Conserv 141: 2184-2192.

MMA - MinistéRIO DO MEIO AMBIENTE. 1999. Ações prioritárias para a conservação da biodiversidade do Cerrado e Pantanal, Ministério do Meio Ambiente, Brasília, DF, 26 p.

MOTTA-JÚNIOR JC. 1990. Estrutura trófica e composição das avifaunas de três habitats terrestres na região central do estado de São Paulo. Ararajuba 1: 65-71.

MYERS N, MitTERMEIER RA, MitTERMEIER CG, FONSECA GAB AND KENT J. 2000. Biodiversity hotspots for conservation priorities. Nature 403: 853-858.

Nunes AP ET AL. 2013. Aves da Serra de Maracaju, Mato Grosso do Sul, Brasil. Rev Bras Ornitol 21(1): 75-100.

OKSANEN J, KIND R, LEGENDRE P, O'HARA B, SIMPSON GL, SOLYMOS P, HenRY M, STEVENS H AND WAGNER H. 2009. Vegan: Community Ecology Package, R package version 1.15-3, http://CRAN.R-project.org/ package= vegan

OLIVEIRA VB, PAGLIA AP, FONSECA M AND GUIMARÃES E. 2010. RPPN e biodiversidade: o papel das reservas particulares na proteção da biodiversidade da Mata
Atlântica, Conservação Internacional, Fundação SOS Mata Atlântica, The Nature Conservancy, Belo Horizonte, $\mathrm{MG}, 48 \mathrm{p}$.

Olmos F, SiLva WAG AND ALBANO CG. 2005. Aves em oito áreas de Caatinga no Sul do Ceará e Oeste de Pernambuco, Nordeste do Brasil: composição, riqueza e similaridade. Pap Avulsos Zool 45: 179-199.

PASCOTTO MC. 2007. Rapanea ferruginea (Ruiz \& Pav) Mez (Myrsinaceae) como uma importante fonte alimentar para as aves em uma mata de galeria no interior do Estado de São Paulo. Rev Bras Zool 24(3): 735-741.

Perfecto I, Rice RA, Greenberg R AND VAN Der VOOT ME. 1996. Shade coffee: a disappearing refuge for biodiversity. BioScience 46: 598-608.

PIMENTEL D, STACHOW U, TAKACS DA, BRUBAKER HW, DUMAS AR, MEANEY JJ, O'NEIL JSA, ONSI DE AND CORZILIUS DB. 1992. Conserving biological diversity in agricultural/forestry systems. BioScience 42: 354-362.

PINESCHI RB. 1990. Aves como dispersoras de sete espécies de Rapanea (Myrsinaceae) no Maciço do Itatiaia, Estados do Rio de Janeiro e Minas Gerais. Ararajuba 1: 73-78.

PIRATELLI A AND BLAKE JG. 2006. Bird communities of the Southeastern Cerrado region, Brazil. Ornitol Neotrop 17: 213-225.

PivatTo MAC, MANÇO DDG, StRAUBE FC, URBEN-FiLho A AND Milano M. 2006. Aves do Planalto da Bodoquena, Estado de Mato Grosso do Sul (Brasil). Atual Ornitol n. 129.

PIZO MA. 2001. A conservação das aves frugívoras. In: Albuquerque JLB et al. (Eds), Ornitologia e conservação: da ciência às estratégias, Editora Unisul, Tubarão, SC, p: 49-59.

POSSO SR, FreitAs MN, BUENO FA, MIZOBE RS, MORANTEFILHO JC AND RAGUSA-NETO J. 2013. Avian composition and distribution in a mosaico of Cerrado habitats (RPPN Parque Ecológico João Basso) in Rondonópolis, Mato Grosso, Brasil. Rev Bras Ornitol 21(4): 243-256.

POTT A AND POTT VJ. 2003. Espécies de fragmentos florestais em Mato Grosso do Sul. In: Costa RBD (Ed), Fragmentação florestal e alternativas de desenvolvimento rural na região centro oeste, UCDB, Campo Grande, MS, p. 26-52.

POZZA DD AND PIRES JSR. 2003. Bird communities in two fragments of semideciduous forest in rural São Paulo state. Braz J Biol 63(2): 307-319.

PRICE OF, WOINARSKI JCZ AND ROBINSON D. 1999. Very large area requirements for frugivorous birds in monsoon rainforests of the Northern Territory, Australia. Biol Conserv 91: 169-180.

R CORE TEAM. 2013. R: A language and environment for statistical computing, R Foundation for Statistical Computing, Vienna, Austria. http://www.R-project.org/.

Reys P, GALETTI M, MOREllato LPC AND SABINO J. 2005. Fenologia reprodutiva e disponibilidade de frutos de espécies arbóreas em mata ciliar no rio Formoso, Mato Grosso do Sul. Biota Neotrop 5(2): 1-10. 
RIBEIRO JF AND WALTER BMT. 1998. Fitofisionomias do bioma Cerrado. In: Sano SM and Almeida SP (Eds), Cerrado: ambiente e flora, Embrapa Cerrados, Brasília, DF, Brasil, p. 89-166.

RICE RA AND GREENBERG R. 2000. Cacao cultivation and the conservation of biological diversity. Ambio 29: 167-173.

RoOs AL, NunEs MFC, SOUZA EA, SOUZA AEBA, NASCIMENTO JLX AND LACERDA RCA. 2006. Avifauna da região do Lago de Sobradinho: composição, riqueza e biologia. Ornithologia 1: 135-160.

SANTOS MPD. 2001. Composição da avifauna nas Áreas de Proteção Ambiental Serra da Tabatinga e Chapada das Mangabeiras, Brasil. Bol Mus Para Emílio Goeldi. Sér Zool 17: 43-67.

SANTOS MPD. 2004. As comunidades de aves em duas fisionomias da vegetação de Caatinga no estado do Piauí, Brasil. Ararajuba 12: 113-123.

SeKercioglu CH, Ehrlich PR, DAILy GC, AYGEN D, GOEHRING D AND SANDI RF. 2002. Disappearance of insectivorous birds from tropical forest fragments. Proc Nat Acad Sci USA 99: 263-267.

SHERRY TW. 2000. Shade coffee: A good brew even in small doses. Auk 117: 563-568.

SICK H. 1997. Ornitologia Brasileira, Editora Nova Fronteira S. A., Rio de Janeiro, RJ, p. 863.

SILVA JMC. 1995. Avian inventory of the Cerrado Region, South America: Implications for biological conservation. Bird Conserv Int 5: 15-28.

SILVA JMC. 1996. Distribution of Amazonian and Atlantic birds in gallery forests of the Cerrado region, South America. Ornitol Neotrop 7: 1-18.

SILVA JMC AND BATES JM. 2002. Biogeographic patterns and conservation in the South American Cerrado: a tropical savanna hotspot. BioScience 52(3): 225-233.

SILVA JMC AND SANTOS MPD. 2005. A importância relativa dos processos biogeográficos na formação da avifauna do Cerrado e de outros biomas brasileiros. In: Scariot A et al. (Eds), Cerrado: Ecologia, Biodiversidade e Conservação, Brasília, DF, p. 439.

SILVA JMC, UHL C AND MURRAY G. 1996. Plant succession, landscape management, and the ecology of frugivorous birds in abandoned Amazonian pastures. Conserv Biol 10: 491-503.

SILVA WR AND VIELliard J. 2004. Avifauna de Mata Ciliar. In: Rodrigues RR and Leitão-Filho HDF (Eds), Matas Ciliares: Conservação e Recuperação, $2^{\mathrm{a}}$ Edição, Edusp, Fapesp, São Paulo, SP, p. 169-186.

SilveIRA LF, OLMOS F AND LONG A. 2003. Birds in Atlantic Forest fragments in northeastern, Brazil. Cotinga 20: 3246.

SILVEIRA MHB AND MACHADO CG. 2012. Estrutura da comunidade de aves em áreas de caatinga arbórea na
Bacia do rio Salitre, Bahia, Brasil. Rev Bras Ornitol 20(3): 161-172.

STOUFFER PC AND BIERREGAARD JR RO. 1995. Use of Amazonian forest fragments by understory insectivorous birds. Ecology 76: 2429-2445.

STRAUBE FC, BORNSCHEIN MR AND SCHERER-NETO P. 1996. Coletânea da avifauna da região noroeste do Estado do Paraná e áreas limítrofes (Brasil). Arq Biol Tec 39(1): 193-214.

TELINO-JÚNIOR WR, DIAS MM, AZEVEDO JÚNIOR SM, LYRA-NEVES RM AND LARRAZÁBAL ME. 2005. Estrutura trófica da avifauna na Reserva Estadual de Gurjaú, Zona da Mata Sul, Pernambuco, Brasil. Rev Bras Zool 22: 962-973.

TELlES M AND DIAS MM. 2010. Bird communities in two fragments of Cerrado in Itirapina, Brazil. Braz J Biol 70(3): 537-550.

TEWS J, BRose U, GRIMM V, TIELBORGERL K, WICHMANN MC, SCHWAGER M AND JELTSCH F. 2004. Animal species diversity driven by habitat heterogeneity/diversity: the importance of keystone structures. J Biogeogr 31: 79-92.

TUBELIS DP AND CAVALCANTI RB. 2000. A comparison of bird communities in natural and disturbed non-wetland open habitats in the Cerrado's central region, Brazil. Bird Conserv Int 10: 331-350.

Tubelis DP AND CAVAlCANTI RB. 2001. Community similarity and abundance of bird species in open habitats of a central Brazilian Cerrado. Ornitol Neotrop 12: 57-73.

TUBELIS DP, COWLING A AND DONNELL C. 2004. Landscape supplementation in adjacent savannas and its implications for the design of corridors for forest birds in the central Cerrado, Brazil. Biol Conserv 118: 353-364.

VALADÃo RM. 2012. As aves da Estação Ecológica Serra das Araras, Mato Grosso, Brasil. Biota Neotrop 12(3): 263 281.

VELOSO HP, RANGEL-FILHO ALR AND LIMA JCA. 1991. Classificação da vegetação brasileira adaptada a um sistema internacional, IBGE, Rio de Janeiro, RJ.

VIEIRA FM, PURIFICAÇÃO KN, CASTILHO LS AND PASCOTTO MC. 2013. Estrutura trófica da avifauna de quatro fitofisionomias de Cerrado no Parque Estadual da Serra Azul. Ornithologia 5(2): 43-57.

VIELLIARD JME, ALMEIDA MEC, ANJOS L AND SILVA WR. 2010. Levantamento quantitativo por pontos de escuta e o Índice Pontual de Abundância (IPA). In: Von Matter S et al. (Eds), Ornitologia e Conservação. Ciência Aplicada, Técnicas de Pesquisa e Levantamento, Technical Books Editora, Rio de Janeiro, RJ, p: 45-60.

WILLIS EO. 1979. The composition of avian communities in remanescent woodlands in southern Brazil. Pap Avulsos Zool 33: 1-25. 


\section{SUPPLEMENTARY MATERIAL}

TABLE SI - Bird species sampled at Estância Mimosa, Bodoquena Mountains, state of Mato Grosso do Sul, Brazil. Trophic groups: I - insectivorous; $\mathrm{O}$ - omnivorous; $\mathrm{F}$ - frugivorous; $\mathrm{G}$ - gramnivorous; $\mathrm{NT}$ - nectarivorous; $\mathrm{C}$ - carnivorous; $\mathrm{N}$ - necrofagous; $\mathrm{P}$ - piscivorous; $\mathrm{M}$
- malacofagous. PAI (Punctual Abundance Index): EM (Estância Mimosa or all the study area), RF (riparian forests or mata ciliar), SF (seasonal forests or mata estacional), WS (woodland savannas or cerradão), AS (arboreal savannas or cerrado stricto sensu), DP (dirty pastures or pasto sujo), CP (clean pastures or pasto limpo); $\mathrm{n}=$ number of samples. 